\title{
Evaluating Biomethane Potential of Inocula from Different Active Biogas Digesters for Palm Oil Mill Effluent by BMP and SMA: Effect of Dilution and Sources
}

\author{
Sawinee SANGSRI ${ }^{1}$, Chairat SIRIPATANA ${ }^{1,2}$, Nirattisai RAKMAK ${ }^{1}$, \\ Pornwimon WADCHASIT ${ }^{1}$ and Sunwanee JIJAI, ${ }^{3, *}$
}

\author{
${ }^{I}$ Department of Civil and Environmental School of Engineering and Resources, Walailak University, \\ Nakhon Si Thammarat 80160, Thailand \\ ${ }^{2}$ Biomass and Oil-Palm Excellence Center, Walailak University, Nakhon Si Thammarat 80160, Thailand \\ ${ }^{3}$ Faculty of Science, Technology and Agriculture, Yala Rajabhat University, Yala 95000, Thailand
}

('Corresponding author’s e-mail: sunwanee.j@yru.ac.th)

Received: 6 March 2019, Revised: 11 December 2019, Accepted: 10 January 2020

\begin{abstract}
This study aims to evaluate how inoculum's origin affects the methane yield of palm oil mill effluent (POME) by measuring the specific methanogenic activities (SMA) and bio-methane potential (BMP) of POME at different dilutions $(100,80,60,40$, and $20 \%$ of initial POME) and by using active anaerobic sludge (as inocula) from 3 palm oil mills $\left(\mathrm{S}_{1}, \mathrm{~S}_{2}, \mathrm{~S}_{3}\right)$. The anaerobic digesters were operated in batch mode at a temperature of $40{ }^{\circ} \mathrm{C}$ until methane generation ceased. The corresponding SMA were $0.0159,0.0098$ and $0.0333 \mathrm{gCOD} /(\mathrm{gVSS} \mathrm{d})$ for $\mathrm{S}_{1}, \mathrm{~S}_{2}$ and $\mathrm{S}_{3}$, respectively. The results showed that POME without dilution gave the highest cumulative biogas, 4162, 2857 and $2678 \mathrm{~mL}$ for $\mathrm{S}_{2}, \mathrm{~S}_{3}$ and $\mathrm{S}_{1}$, respectively. However, $20 \%$ dilution from original POME gave the highest methane yield (as BMP) 126, 88 and $84 \mathrm{~mL} \mathrm{CH}_{4} / \mathrm{gCOD}$ removed for $\mathrm{S}_{2}, \mathrm{~S}_{3}$ and $\mathrm{S}_{1}$, respectively. In this study, 2 mathematical models were selected including the corrected Gompertz equation and Gompertz two substrate models. They were applied to characterize the kinetics of the anaerobic digestion processes and to compare the BMP data from the experiments. Both models could represent all BMP data satisfactory although only Gompertz 2 substrate model showed almost perfect fitting and could characterize the influence of slowly degradable portion of POME. Accordingly, the slowly degradable portion of POME was estimated to be $10 \%$ of total COD.
\end{abstract}

Keywords: Inoculum for anaerobic digestion, Start-up of biogas digesters, Gompertz 2 substrate model, POME, SMA versus BMP tests

\section{Introduction}

Currently, palm oil industry is the biggest agro-industry in southern Thailand. The expansion of the palm oil industry in the last 20 years has caused a great concern for its impact on the environment. In the production of crude palm oil, large amount of water is required, resulting in the generation of large quantity of polluted wastewater which is commonly referred to as palm oil mill effluent (POME)[1]. Anaerobic digestion system is suitable for the POME treatment in the performance of anaerobic digestion of POME where $62-98 \%$ of COD reduction and gave $39-84 \%$ of methane production [2]. Because of its highly energy intensive, the government promotion for renewable energy and the suitable physicochemical characteristics of POME for biogas production by anaerobic digestion, most palm oil mills (POM) have built and operated biogas power plants to trap more profit from lowering their energy cost or even selling electricity to the electricity authority. This trend has changed how POM manages waste and 
wastewater almost entirely. Now all wastes and wastewater from POMs in Southern Thailand become an asset which can be sold and can substitute fossil oil and electricity for energy need in the plants. However, biogas plant from POME needs is a big investment and anaerobic digestion (AD) is very notorious for its instability, being susceptible to physico-chemical and environmental disruptions, suboptimal operation and long start-up time [3].

Although biogas plants for POME and its related technology are relatively well established, there are still many questions arising on how to squeeze most $\mathrm{CH}_{4}$ out of it while lowering the operation cost and enhancing the process stability. This research is related to how to start the AD process effectively. Thus, we want to answer 2 basic questions related to biogas-plant start-up: firstly, how the origin of startup inoculum affects the start-up time and specific biomethane yield; secondly, what level of dilution would help to speed up the start-up period, giving best yield so it would be an optimal dilution for start-up period and during normal operation.

\section{Materials and methods}

The wastewater sample was collected from a biogas plant in a palm oil mill factory located in Nakhon Si Thammarat $\left(\mathrm{WS}_{1}\right)$. The sludge/inoculum from 3 sources were collected from active biogas digesters in palm oil mill factories located in Palmdee Si Nakorn company limited in Huasai district, Nakhon Si Thammarat province $\left(\mathrm{S}_{1}\right)$, Phrasaeng-green-power company limited in Phrasaeng district, Suratthani province $\left(\mathrm{S}_{2}\right)$ and Mit Prasong Green Power company limited in Tha Chana district, Suratthani province $\left(\mathrm{S}_{3}\right)$. The samples were stored at room temperature until used in the experiment. After the determination of its physicochemical properties, the characteristics of wastewater are shown in Table 1. The wastewater was stored in a sealed container and kept in a cold room at $4{ }^{\circ} \mathrm{C}$ until being used.

Table 1 Basic parameters of palm oil mill effluent (POME).

\begin{tabular}{ccccccccc}
\hline Parameter & pH & $\mathbf{C O D}(\mathrm{g} / \mathbf{L})$ & $\mathbf{T K N}(\mathbf{m g} / \mathbf{L})$ & $\mathbf{T P}(\mathbf{m g} / \mathbf{L})$ & $\mathbf{T S}(\mathrm{g} / \mathbf{L})$ & $\mathbf{V S}(\mathbf{g} / \mathbf{L})$ & $\mathbf{S S}(\mathrm{g} / \mathbf{L})$ & $\mathbf{V S S}(\mathrm{g} / \mathbf{L})$ \\
\hline Value & $4.68 \pm 0.04$ & $86.8 \pm 2.23$ & $1043 \pm 8.89$ & $267 \pm 4.00$ & $56.61 \pm 0.07$ & $45.41 \pm 0.55$ & $35.85 \pm 1.07$ & $31.27 \pm 1.03$ \\
\hline
\end{tabular}

\section{Experiment I: determination of specific methanogenic activity (SMA) of 3 granules/inocula}

An inoculum activity test was performed using SMA assay to evaluate the activity of methanogens in the sludge/inoculum from 3 sources. The assay was conducted in $500 \mathrm{~mL}$ serum glass bottles with 275 $\mathrm{mL}$ effective volume which contains acetic acid as a substrate and other nutrient supplements according to [4]. Each serum bottle contained $250 \mathrm{~mL}$ of inoculum with $25 \mathrm{~mL}$ of $1 \mathrm{gCOD}$ acetic acid. To ensure 0 baselines, 3 bottles of blank contained only $250 \mathrm{~mL}$ of inocula $\left(\mathrm{S}_{1}, \mathrm{~S}_{2}\right.$ and $\left.\mathrm{S}_{3}\right)$ and filled up with DI water were used as control. Biogas production and its compositions were measured every hour for $24 \mathrm{~h}$ with a graduate glass syringe [5]. The details of the experimental design for each reactor are given below:

Reactor 1: Inocula $\left(\mathrm{S}_{1}\right)+$ synthetic wastewater

Reactor 2: Inocula $\left(\mathrm{S}_{2}\right)+$ synthetic wastewater

Reactor 3: Inocula $\left(\mathrm{S}_{3}\right)+$ synthetic wastewater

Reactor 4: Inocula $\left(\mathrm{S}_{1}\right)+$ distilled water (Blank)

Reactor 5: Inocula $\left(\mathrm{S}_{2}\right)+$ distilled water (Blank)

Reactor 6: Inocula $\left(\mathrm{S}_{3}\right)+$ distilled water (Blank) 
Experiment II (BMP): determination of biochemical methane potential (BMP) of substrate dilution (\%POME from $\mathrm{WS}_{1}$ ) associated with sludge/inoculum from 3 sources

The BMP experiments were conducted in a batch system at temperature $40{ }^{\circ} \mathrm{C}$. The $500-\mathrm{mL}$-volume serum bottles having a working volume of $300 \mathrm{~mL}$ were used as the reactor in all experiments. The BMP test was conducted using the method proposed by Owen et al. [7] with at least 3 replications. The initial $\mathrm{pH}$ for all reactors was adjusted to $7.0-7.5$ by the addition of $1 \mathrm{~N} \mathrm{NaOH}$. The digesters were sealed with rubber plugs and tied up with aluminum caps. Biogas production was measured daily by water displacement method as used by other authors [5-8]. The methane content was measured using KOH solution displacement in a serum bottle, as described previously [9].

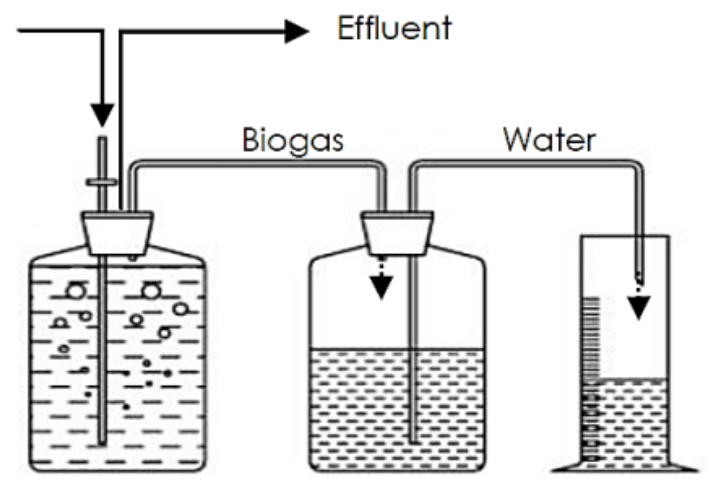

Figure 1 Schematic view of the experimental set-up in batch mode.

The sludge/inoculum from 3 sources was used in the BMP assays which were carried out in 3 reactors. Each reactor contains different inoculum and different dilution levels of the same wastewater source $\left(\mathrm{WS}_{1}\right)$. The detail of each reactor setup was as follows: the variables designed in this study were shown in Table 2. All experiments were carried out in 3 replications.

Reactor 1: Inocula $\left(\mathrm{S}_{1}\right)+$ Wastewater $\left(\mathrm{WS}_{1}\right)$

Reactor 2: Inocula $\left(\mathrm{S}_{2}\right)+$ Wastewater $\left(\mathrm{WS}_{1}\right)$

Reactor 3: Inocula $\left(\mathrm{S}_{3}\right)+$ Wastewater $\left(\mathrm{WS}_{1}\right)$

Table 2 Experimental design for BMP test in Batch mode.

\begin{tabular}{ccccc}
\hline Digester & $\begin{array}{c}\text { POME } \\
(\mathbf{m L})\end{array}$ & Inocula (mL) & Total working volume (mL) & Dilution POME (\%) \\
\hline 1 & 60 & 240 & 300 & 100 \\
2 & 60 & 240 & 300 & 80 \\
3 & 60 & 240 & 300 & 60 \\
4 & 60 & 240 & 300 & 40 \\
5 & 60 & 240 & 300 & 20 \\
\hline
\end{tabular}

\section{Chemical analysis in the batch system}

Chemical oxygen demand (COD), Total Kjeldahl Nitrogen (TKN), Total Phosphorus (TP), Total Solids (TS), Volatile Solids (VS), Suspended Solids (SS), Volatile Suspended Solids (VSS) and pH were analyzed. All analytical procedures were performed in accordance with standard methods for the examination of water and wastewater [10]. 


\section{Kinetic models}

Two kinetic models were used to describe methane evolution (ME) data, namely: corrected Gompertz model [11] and Gompertz 2 substrate model [12].

\section{Corrected Gompertz model}

Siripatana et al. [11] analyzed Gompertz model as used to describe the batch AD process and came up with a corrected Gompertz model. That is;

$$
\mathrm{P}=\left(\mathrm{P}_{\infty}+\mathrm{P}_{0}^{\prime}\right) \exp \left(-\exp \left(\frac{\mathrm{R}_{\mathrm{m}} \mathrm{e}}{\mathrm{P}_{\infty}+\mathrm{P}_{0}}\left(\lambda_{\mathrm{e}}-\mathrm{t}\right)+1\right)\right)-\mathrm{P}_{0}^{\prime}
$$

where $P$ is accumulated biogas (or methane) produced up to time $t, P_{\infty}$ is the ultimately accumulated biogas produced as $P, P_{0}^{\prime}$ is non-observable biogas produced by the active cell biomass before $t=0$, $R_{m}$ is the methane generation rate, $e=\exp (1), \lambda_{e}$ lag time.

This work used a corrected form of Gompertz model because it removes initial error due to unobserved biogas which was produced before the anaerobic digestion started. Thus, the model ensures that at 0 time, the model gives no accumulated biogas. This error was discussed in length in Siripatana et al. [11].

\section{The Gompertz 2 substrate model}

Noynoo et al. [12] used Gompertz postulation and rewrote the specific growth rate as a time function of the Gompertz 2 substrate model as shown below;

$$
\mathrm{P}=\left(1-\mathrm{f}_{\mathrm{s}}\right)\left(\mathrm{P}_{\infty}+\mathrm{P}_{0}^{\prime}\right) \exp \left(-\exp \left(\frac{\mathrm{R}_{\mathrm{me}} \mathrm{e}}{\left(1-\mathrm{f}_{\mathrm{s}}\right)\left(\mathrm{P}_{\infty}+\mathrm{P}_{0}^{\prime}\right)}\left(\lambda_{\mathrm{e}}-\mathrm{t}\right)+1\right)\right)-\mathrm{P}_{0}^{\prime}+\mathrm{g}(\mathrm{t}) \mathrm{f}_{\mathrm{s}}\left(\mathrm{P}_{\infty}+\mathrm{P}_{0}^{\prime}\right) \exp \left(-\exp \left(\frac{\mathrm{R}_{\mathrm{m}} \mathrm{e}}{\mathrm{fs}_{\mathrm{s}}\left(\mathrm{P}_{\infty}+\mathrm{P}_{0}^{\prime}\right)}\left(\mathrm{t}_{\mathrm{c}}-\mathrm{t}\right)+1\right)\right)
$$

where $f_{s}$ is a fraction of slowly degradable in Eq. (2) if we set $f_{s}=0.1$.

Here $g(t)$ is the switching or preference function which describes how the microorganisms switch from one preferred substrate to another less preferred one. And $g(t)$ was proposed as follows and its graphical representation is depicted in Figure 2.

$$
g(t)=\frac{1}{\pi}\left(\tan ^{-1}(\kappa(t-t))+\frac{\pi}{2}\right)
$$

where $\mathrm{K}$ is preference gain which describes how the presence of $1^{\text {st }}$ substrate affects on the consumption rate of the second one and $t_{c}$ is the switching time.

Traditional Gompertz-type models were developed based on single (limiting) substrate so it cannot represent the accumulative biogas curves for batch $\mathrm{AD}$ having more than one substrate very well. Although in reality, POME contains multiple substrates in itself, and 2 substrate entities having a different degree of degradability are sufficient for representing the wastewater in AD process. Thus, the Gompertz 2 substrate model is the extension of the traditional Gompertz model to tackle multiple substrates. This approach is similar to that used in Anaerobic Digestion Model I (ADM1) developed by the consortium of $\mathrm{AD}$ experts in 2002 [13]. 
http://wjst.wu.ac.th

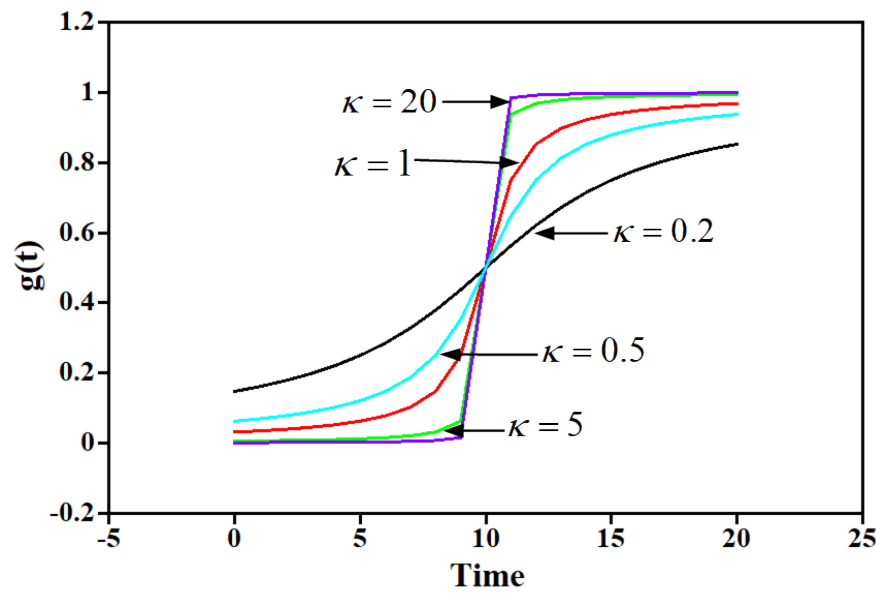

Figure 2 Graphical representation of $g(t)$.

\section{Results and discussion}

The specific methanogenic activity (SMA)

The SMA assay is widely accepted to represent the potential of microbial activity in anaerobic digestion and thus is useful for the startup, operation and control of the anaerobic digestion process. It is also simple and convenient for evaluating inoculum before the start-up of biogas digesters. The SMA of sludge/inoculum from 3 sources is shown in Table 3. SMA of inoculum from $\mathrm{S}_{3}$ was highest among 3 sources (0.0333 $\mathrm{gCOD} / \mathrm{gVSSd})$, including inoculums from $\mathrm{S}_{1}$ and $\mathrm{S}_{2}(0.0159$ and $0.0098 \mathrm{gCOD} / \mathrm{gVSSd})$, respectively. The cumulative methane at the end of the experiment was in the ranged from $560-1216 \mathrm{~mL}$ be visualized in Figure 3.

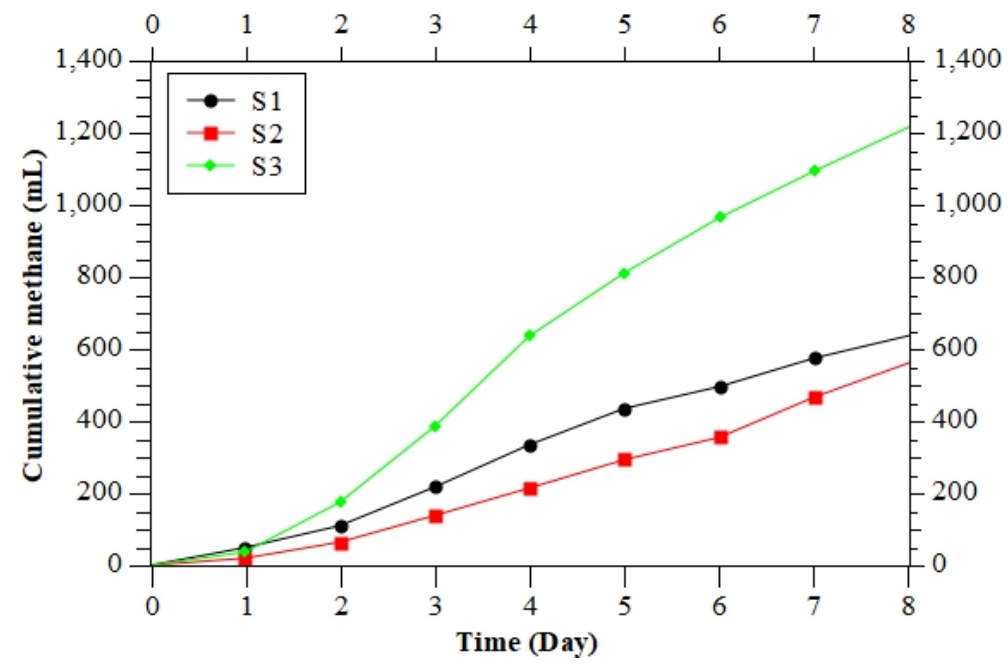

Figure 3 Comparison of cumulative methane VS time between $S_{1}, S_{2}$ and $S_{3}$. 
Table 3 Specific methanogenic activities (SMA).

\begin{tabular}{cc}
\hline Inocula sources & SMA $(\mathbf{g C O D} / \mathbf{g V S S} \cdot \mathbf{d})$ \\
\hline $\mathrm{S}_{1}$ & 0.0159 \\
$\mathrm{~S}_{2}$ & 0.0098 \\
$\mathrm{~S}_{3}$ & 0.0333 \\
\hline
\end{tabular}

\section{The biochemical methane potential (BMP)}

The result of this study in experiment II is shown in Table 4, which summarizes the effect of sludge/inoculum from 3 sources at different dilutions (100, 80, 60, 40, and $20 \%$ of initial POME). All long-term accumulative biogas/methane volumes were estimated by fitting the data to Gompertz 2 substrate model developed by Noynoo et al. [12]. At the end of the BMP test, the cumulative biogas production from all digesters reached the value of $670-4162 \mathrm{~mL}$ and the average methane content was 46.7, 49.7 and $45.4 \%$ for $S_{1}, S_{2}$ and $S_{3}$, respectively. The results showed that POME without dilution gave highest cumulative biogas. The cumulative methane at the end of the experiments was in the range of $268-2112 \mathrm{~mL}$. It was observed that the digester which used $20 \%$ of wastewater from original POME gave the highest methane yield as shown in Figure $4\left(126,88\right.$ and $84 \mathrm{~mL} \mathrm{CH}_{4} / \mathrm{gCOD}_{\text {removed }}$ for $\mathrm{S}_{2}, \mathrm{~S}_{3}$ and $\mathrm{S}_{1}$, respectively). The results showed that the diluted wastewater (used $20 \%$ from POME original) gave better results than that from the original wastewater. This could be attributed to better nutrient balance $(\mathrm{COD} / \mathrm{N})$ and environmental conditions suitable for the microorganism in anaerobic digestion and balance between substrate: microorganism [14]. Thus, it was clearly indicated that there was a weak substrate inhibition at high COD which negatively affected the methane production [15].

It is interesting to note that inoculum $\mathrm{S}_{2}$ not only gave the highest amount of biogas volume in all POME dilutions, but it also generated richer methane in biogas (Table 5). Thus, the composition of biogas depends not only on the substrate composition but also on the activity of the microorganisms in the sludge although the influence of the later is minor but observable.

Table 4 The cumulative biogas and methane for different inoculum sources and dilutions.

\begin{tabular}{ccccccc}
\hline Dilution POME (\%) & $\mathbf{1 0 0}$ & $\mathbf{8 0}$ & $\mathbf{6 0}$ & $\mathbf{4 0}$ & $\mathbf{2 0}$ \\
\hline COD (mg/L) & & $86400 \pm 1571.62$ & $64000 \pm 2286.92$ & $52800 \pm 1571.62$ & $46400 \pm 2233.83$ & $16000 \pm 1931.32$ \\
\hline \multirow{2}{C}{$\begin{array}{c}\text { COD removal } \\
(\%)\end{array}$} & $\mathbf{S}_{\mathbf{1}}$ & $82.9 \pm 1.53$ & $89 \pm 1.01$ & $89.1 \pm 0.53$ & $95.8 \pm 0.16$ & $86 \pm 6.59$ \\
& $\mathbf{S}_{\mathbf{2}}$ & $90.4 \pm 0.41$ & $88.0 \pm 0.37$ & $90.9 \pm 0.27$ & $94.5 \pm 0.58$ & $91.7 \pm 1.38$ \\
& $\mathbf{S}_{\mathbf{3}}$ & $91.1 \pm 0.19$ & $92 \pm 0.42$ & $91.5 \pm 0.75$ & $93.1 \pm 0.65$ & $84 \pm 2.26$ \\
\hline \multirow{2}{*}{ Cumulative } & $\mathbf{S}_{\mathbf{1}}$ & $2678.4 \pm 41.71$ & $2083.3 \pm 40.80$ & $1705.1 \pm 37.65$ & $1298.6 \pm 46.35$ & $670.2 \pm 34.06$ \\
biogas (ml) & $\mathbf{S}_{\mathbf{2}}$ & $4162.3 \pm 28.05$ & $3364.4 \pm 37.57$ & $3202 \pm 67.75$ & $2222.8 \pm 79.24$ & $1211.9 \pm 21.22$ \\
& $\mathbf{S}_{\mathbf{3}}$ & $2857.1 \pm 30.07$ & $2190.9 \pm 27.34$ & $1878.9 \pm 44.63$ & $1208.6 \pm 32.65$ & $845 \pm 18.45$ \\
\hline \multirow{3}{*}{ Cumulative } & $\mathbf{S}_{\mathbf{1}}$ & $1349.3 \pm 39.18$ & $1041.3 \pm 31.38$ & $837.3 \pm 10.9$ & $569.5 \pm 22.94$ & $268.2 \pm 18.84$ \\
methane (ml) & $\mathbf{S}_{\mathbf{2}}$ & $2111.9 \pm 15.79$ & $1569.4 \pm 12.93$ & $1674.2 \pm 47.00$ & $1162 \pm 36.12$ & $557.7 \pm 12.90$ \\
& $\mathbf{S}_{\mathbf{3}}$ & $1394.3 \pm 23.72$ & $986.2 \pm 26.50$ & $880.4 \pm 31.41$ & $537.7 \pm 13.42$ & $356.7 \pm 20.16$ \\
\hline
\end{tabular}


http://wjst.wu.ac.th

Table 5 The average methane content in biogas for different inoculum sources and dilutions.

\begin{tabular}{|c|c|c|c|c|c|c|c|}
\hline \multirow{2}{*}{$\begin{array}{l}\text { Dilution POME } \\
(\%)\end{array}$} & \multicolumn{3}{|c|}{ Batch average $\mathrm{CH}_{4}$ content $\left(\% \mathrm{CH}_{4}\right)$} & \multirow{2}{*}{$\begin{array}{c}\text { Average } \% \mathrm{CH}_{4} \\
\text { for different } \\
\text { dilutions }\end{array}$} & \multicolumn{3}{|c|}{$\begin{array}{c}\text { Methane yield } \\
\text { (ml CH} / \text { gCOD }_{\text {removed }} \text { ) }\end{array}$} \\
\hline & $\mathbf{S}_{1}$ & $\mathbf{S}_{2}$ & $\mathbf{S}_{3}$ & & $\mathbf{S}_{1}$ & $\mathbf{S}_{2}$ & $\mathbf{S}_{3}$ \\
\hline 100 & $50.4 \pm 1.61$ & $50.7 \pm 0.82$ & $48.8 \pm 1.44$ & $50.1 \pm 1.29$ & $62.7 \pm 1.44$ & $90.2 \pm 1.26$ & $59.0 \pm 1.02$ \\
\hline 80 & $50.0 \pm 0.96$ & $47.0 \pm 0.96$ & $45.0 \pm 0.58$ & $47.3 \pm 0.83$ & $60.9 \pm 2.79$ & $92.9 \pm 3.17$ & $55.8 \pm 2.21$ \\
\hline 60 & $49.1 \pm 1.52$ & $52.3 \pm 1.24$ & $46.9 \pm 1.26$ & $49.4 \pm 1.34$ & $59.3 \pm 2.07$ & $116.2 \pm 3.64$ & $60.7 \pm 2.12$ \\
\hline 40 & $43.9 \pm 1.46$ & $52.3 \pm 1.35$ & $44.5 \pm 0.67$ & $46.9 \pm 1.16$ & $42.7 \pm 2.14$ & $88.3 \pm 4.82$ & $41.5 \pm 2.27$ \\
\hline 20 & $40.0 \pm 0.86$ & $46.0 \pm 0.68$ & $42.2 \pm 0.54$ & $42.7 \pm 0.69$ & $84.6 \pm 18.13$ & $126.7 \pm 16.81$ & $88.5 \pm 12.85$ \\
\hline $\begin{array}{l}\text { Average } \% \mathrm{CH}_{4} \text { for } \\
\text { different sources }\end{array}$ & $46.7 \pm 1.28$ & $49.7 \pm 1.01$ & $45.4 \pm 0.90$ & $47.3 \pm 10.6$ & & & \\
\hline
\end{tabular}

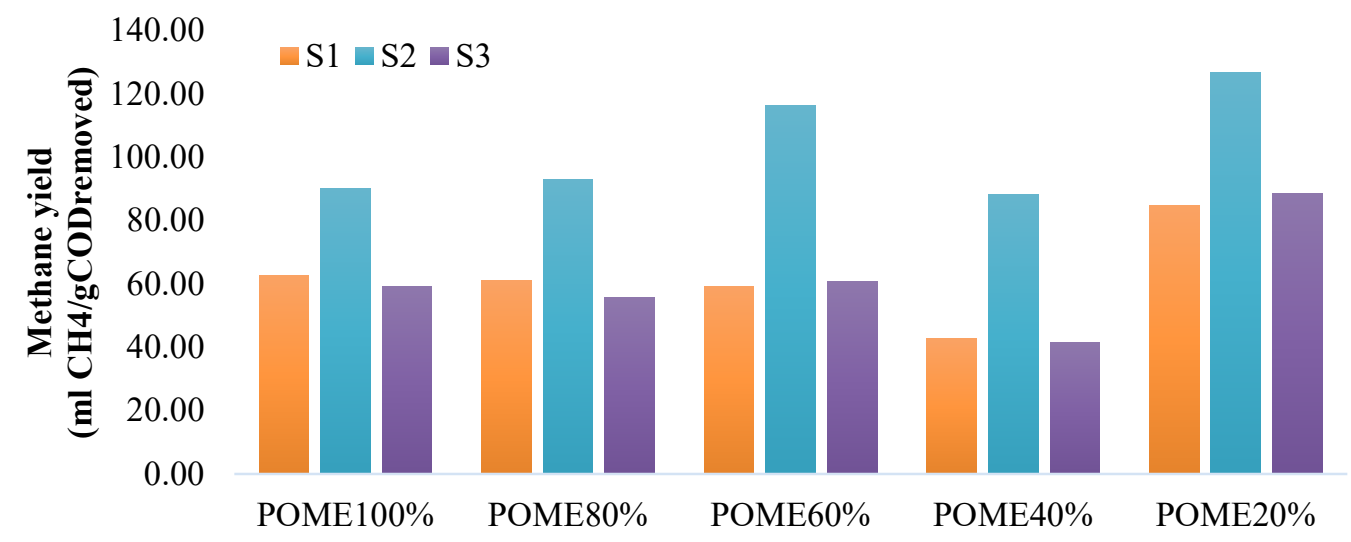

Figure 4 Methane yield.

\section{Inoculum for the start-up: SMA versus BMP}

Regarding the best inoculum among three sources, the results of SMA and BMP assays did not agree with each other. While the $\left(\mathrm{SMA}\right.$ of $\left.\mathrm{S}_{3}\right)>\left(\mathrm{SMA}\right.$ of $\left.\mathrm{S}_{1}\right)>\left(\mathrm{SMA}\right.$ of $\left.\mathrm{S}_{2}\right)$, the inoculum from $\mathrm{S}_{2}$ gave the best BMP among three sources of inocula for all POME dilutions. Thus, the question arises "which one SMA or BMP results should be used to choose the best inoculum for starting up the new biogas plant?" Based on the results (SMA and BMP assays), the use of BMP assays over SMA counterparts is recommended based on the following arguments. Firstly, BMP assays give direct results by allowing the pair of inoculum-substrate has full interaction, thus reflecting potential overall performance which involves all steps of the AD process (hydrolysis, acedogenesis, acetogenesis and methanogenesis). On the contrary, SMA assay measures the methanogenic activity of an inoculum when it acts on the simplest substrate (acetate) and produces methane. Thus, SMA is not a comprehensive test. These results indicated that in this study, inoculum source could significantly affect the ultimate methane yield.

Secondly, it can mislead us by assuming that methanogenesis can represent (or at least an index) the whole AD process which is not quite true as observed in this work. Last but not least, each substrate has its own particularity which is difficult to predict unless an actual AD test (such as BMP test) is performed. SMA has no direct connection to any particular substrate except acetate, the simplest substrate for mathanogenesis step. Therefore, it lacks the quality to fully reflect the effect of inoculum on the performance of POME anaerobic digestion in general. 


\section{Kinetics of batch AD}

More insight can be obtained from the analysis of the kinetics of BMP data in the form of methane evolution (ME) curves (Tables 5 - 7). In this work, Gompertz 2 substrate model can represent ME curves very satisfactory whereas the traditional modified Gompertz equation could not match the shape of the curves very well. According to Noynoo et al. [12], these ME curves resemble the so-called "type II and III" in which the substrate can be represented as having 2 portions: easily and slowly degradable substrates. A good estimate fraction of slowly degradable $\left(f_{S}\right)$ was 0.1 for POME in all dilutions. The initial methane production rate $\left(\mathrm{R}_{\mathrm{me}}\right)$ is a good indicator of methanogenic activity for the corresponding inoculum. It was obvious that $\mathrm{R}_{\mathrm{me}}$ of $\mathrm{S}_{2}$ was the highest among the sludge/inoculum from 3 sources. Since, in all runs, \%COD removal was of similar magnitude (83 - $95 \%$ with small fluctuation) and POME contained mostly easily digestible substrate $(\sim 90 \%), \mathrm{S}_{2}$ inoculum gave the highest BMP because of its fast nutrient consumption (high $\mathrm{R}_{\mathrm{me}}$ ) which could push $\mathrm{AD}$ toward more methanogenesis with smaller lost due to heat and cell growth, thus giving the higher methane yield. This would explain why $\mathrm{S}_{2}$ inoculum was the most active and effective inoculum, suitable for use in starting up a new biogas plant or digester.

Another interesting parameter was the time lag $\lambda_{\mathrm{e}}$ which normally has a positive value unless it has to start at batch $\mathrm{AD}$ with an excessive load of active microorganisms, creating a condition in which the substrate is not enough for all microbes to consume it simultaneously. This is exactly the case for our BMP assay and it is considered a usual characteristic of a healthy BMP test.

Table 6 Parameters and the best-fit parameter $\left(\mathrm{R}^{2}\right)$ of cumulative methane production for Correct Gompertz model.

\begin{tabular}{ccccccc}
\hline \multirow{2}{*}{ Dilution POME $(\%)$} & \multicolumn{5}{c}{ Parameter } \\
\cline { 2 - 7 } & & $\mathbf{P}_{\mathbf{0}}(\mathbf{m L})$ & $\mathbf{P}_{\text {inf }}(\mathbf{m L})$ & $\mathbf{R}_{\mathbf{m}}(\mathbf{m L} / \mathbf{d})$ & $\boldsymbol{\lambda}(\mathbf{d})$ & $\mathbf{R}^{\mathbf{2}}$ \\
\hline \multirow{2}{*}{$\mathbf{1 0 0}$} & $\mathbf{S}_{\mathbf{1}}$ & $96.88 \pm 28.6$ & $1290 \pm 16.8$ & $132.03 \pm 8.0$ & -0.3 & $\mathbf{0 . 9 9 5 7}$ \\
& $\mathbf{S}_{\mathbf{2}}$ & $179.73 \pm 47.0$ & $2101 \pm 34.3$ & $151.41 \pm 8.3$ & -1.1 & $\mathbf{0 . 9 9 4 3}$ \\
& $\mathbf{S}_{\mathbf{3}}$ & $216.17 \pm 35.4$ & $1350 \pm 11.9$ & $231.72 \pm 12.5$ & -0.9 & $\mathbf{0 . 9 9 6 4}$ \\
\hline \multirow{3}{*}{$\mathbf{8 0}$} & $\mathbf{S}_{\mathbf{1}}$ & $92.23 \pm 22.3$ & $1006 \pm 12.9$ & $126.2 \pm 7.3$ & -0.3 & $\mathbf{0 . 9 9 6 3}$ \\
& $\mathbf{S}_{\mathbf{2}}$ & $133 \pm 28.0$ & $1516 \pm 14.9$ & $160.21 \pm 6.8$ & -0.5 & $\mathbf{0 . 9 9 6 1}$ \\
& $\mathbf{S}_{\mathbf{3}}$ & $193.13 \pm 40.7$ & $945 \pm 12.7$ & $201.18 \pm 14.9$ & -1 & $\mathbf{0 . 9 9 1 1}$ \\
\hline \multirow{2}{*}{$\mathbf{6 0}$} & $\mathbf{S}_{\mathbf{1}}$ & $69 \pm 32.1$ & $773 \pm 15.9$ & $104 \pm 11.0$ & -0.35 & $\mathbf{0 . 9 8 7 1}$ \\
& $\mathbf{S}_{\mathbf{2}}$ & $134 \pm 32.5$ & $1651 \pm 16.5$ & $190 \pm 1.9$ & -0.2 & $\mathbf{0 . 9 9 5 7}$ \\
& $\mathbf{S}_{\mathbf{3}}$ & $152.01 \pm 45.9$ & $822 \pm 17.4$ & $189.47 \pm 1.9$ & -0.8 & $\mathbf{0 . 9 8 5 5}$ \\
\hline \multirow{2}{*}{$\mathbf{4 0}$} & $\mathbf{S}_{\mathbf{1}}$ & $69.28 \pm 35.2$ & $512 \pm 14.6$ & $68 \pm 9.9$ & -1.1 & $\mathbf{0 . 9 7 0 7}$ \\
& $\mathbf{S}_{\mathbf{2}}$ & $105.11 \pm 32.1$ & $1123 \pm 17.5$ & $157.43 \pm 10.0$ & -0.15 & $\mathbf{0 . 9 9 1 7}$ \\
& $\mathbf{S}_{\mathbf{3}}$ & $96.45 \pm 12.3$ & $491.1 \pm 16.5$ & $117.32 \pm 8.7$ & -1 & $\mathbf{0 . 9 7 1 7}$ \\
\hline & $\mathbf{S}_{\mathbf{1}}$ & $27.33 \pm 18.6$ & $237.21 \pm 8.9$ & $14.27 \pm 2.4$ & -3.7 & $\mathbf{0 . 9 6 1 3}$ \\
& $\mathbf{S}_{\mathbf{2}}$ & $48.25 \pm 21.6$ & $514.27 \pm 10.5$ & $84.7 \pm 7.6$ & -0.3 & $\mathbf{0 . 9 8 5}$ \\
& $\mathbf{S}_{\mathbf{3}}$ & $72.12 \pm 50.0$ & $325.08 \pm 14.6$ & $33.29 \pm 8.7$ & -3.5 & $\mathbf{0 . 9 3 7 7}$ \\
\hline
\end{tabular}


Table 7 Parameters and the best-fit parameter $\left(\mathrm{R}^{2}\right)$ of cumulative methane production for Gompertz two substrate model.

\begin{tabular}{|c|c|c|c|c|c|c|c|c|c|c|}
\hline \multirow{2}{*}{\multicolumn{2}{|c|}{$\begin{array}{c}\text { Dilution } \\
\text { POME (\%) }\end{array}$}} & \multicolumn{9}{|c|}{ parameter } \\
\hline & & $P_{0}(m L)$ & $\mathbf{P} \infty(\mathrm{mL})$ & $\mathbf{R}_{\mathrm{me}}(\mathbf{m L} / \mathbf{d})$ & $\mathbf{R}_{\mathrm{ms}}$ & $\mathbf{f}_{\mathrm{s}}$ & $\mathbf{k}$ & $\lambda(d)$ & $t_{c}(d)$ & $\mathbf{R}^{2}$ \\
\hline \multirow{3}{*}{100} & $\mathbf{S}_{1}$ & $96.88 \pm 28.6$ & $1392 \pm 22.9$ & $132.03 \pm 8.0$ & $7.347 \pm 9.1$ & 0.1 & $0.0212 \pm 0.0$ & -0.3 & $24.81 \pm 1.2$ & 0.9986 \\
\hline & $\mathbf{S}_{2}$ & $179.73 \pm 47.0$ & $2078 \pm 33.2$ & $151.41 \pm 8.3$ & $2.87 \pm 2.4$ & 0.1 & $1.58 \pm 3.3$ & -1.1 & $10.27 \pm 2.5$ & 0.9977 \\
\hline & $\mathbf{S}_{\mathbf{3}}$ & $216.17 \pm 35.39$ & $1393.96 \pm 10.0$ & $231.72 \pm 12.5$ & $5.11 \pm 1.00$ & 0.1 & $39.75 \pm 10.1$ & -0.9 & $0.17974 \pm 1.7$ & 0.9996 \\
\hline \multirow{3}{*}{80} & $\mathbf{S}_{1}$ & $92.23 \pm 22.3$ & $1048 \pm 26.9$ & $126.2 \pm 7.3$ & $2.75 \pm 1.5$ & 0.1 & $2.607 \pm 3.3$ & -0.3 & $3.3911 \pm 4.2$ & 0.9988 \\
\hline & $\mathbf{S}_{\mathbf{2}}$ & $133 \pm 28.0$ & $1589 \pm 46.5$ & $160.21 \pm 6.8$ & $3.089 \pm 1.8$ & 0.1 & $4.3733 \pm 5.11$ & -0.5 & $1.49 \pm 3.77$ & 0.9986 \\
\hline & $\mathbf{S}_{3}$ & $193.13 \pm 40.7$ & $984.48 \pm 12.3$ & $201.18 \pm 14.9$ & $3.21 \pm 0.9$ & 0.1 & $18.77 \pm 5.6$ & -1 & $0.3677 \pm 2.6$ & 0.9989 \\
\hline \multirow{3}{*}{60} & $\mathbf{S}_{1}$ & $69 \pm 32.1$ & $823 \pm 10.9$ & $104 \pm 11.0$ & $4.44 \pm 3.2$ & 0.1 & $0.2583 \pm 0.5$ & -0.35 & $23.91 \pm 6.8$ & 0.9972 \\
\hline & $\mathbf{S}_{2}$ & $134 \pm 32.5$ & $1690 \pm 15.3$ & $190 \pm 1.9$ & $343 \pm 5.3$ & 0.1 & $0.0329 \pm 0.2$ & -0.2 & $5.24 \pm 2.7$ & 0.9957 \\
\hline & $\mathbf{S}_{3}$ & $152.01 \pm 45.9$ & $877.64 \pm 19.8$ & $189.47 \pm 1.9$ & $3.81 \pm 3.5$ & 0.1 & $4.6 \pm 1.6$ & -0.8 & $10.2894 \pm 7.9$ & 0.9954 \\
\hline \multirow{3}{*}{40} & $\mathbf{S}_{1}$ & $69.28 \pm 36.2$ & $543 \pm 10.9$ & $68 \pm 9.9$ & $4.98 \pm 10.7$ & 0.1 & $0.343 \pm 0.0$ & -1.1 & $25.12 \pm 10.2$ & 0.9906 \\
\hline & $\mathbf{S}_{2}$ & $105.11 \pm 32.1$ & $1202 \pm 4.06$ & $157.43 \pm 10.0$ & $2 \pm 1.23$ & 0.1 & $2.6954 \pm 5.71$ & -0.15 & $4.26 \pm 7.42$ & 0.9925 \\
\hline & $\mathrm{S}_{3}$ & $96.45 \pm 12.3$ & $524.37 \pm 10.7$ & $117.32 \pm 8.7$ & $3.97 \pm 6.0$ & 0.1 & $0.07 \pm 0.0$ & -1 & $12.284 \pm 1.2$ & 0.9874 \\
\hline \multirow{3}{*}{20} & $S_{1}$ & $27.33 \pm 18.6$ & $254.86 \pm 10.3$ & $14.27 \pm 2.4$ & $2.442 \pm 17.7$ & 0.1 & $0.0345 \pm 0.6$ & -3.7 & $31.87 \pm 50.1$ & 0.9753 \\
\hline & $\mathbf{S}_{2}$ & $48.25 \pm 21.6$ & $537.62 \pm 10.8$ & $84.7 \pm 7.6$ & $1.4093 \pm 1.5$ & 0.1 & $12.46 \pm 3.3$ & -0.3 & $2.91 \pm 1.1$ & 0.9944 \\
\hline & $\mathbf{S}_{\mathbf{3}}$ & $72.12 \pm 50.0$ & $339.05 \pm 53.9$ & $33.29 \pm 8.7$ & $3.83 \pm 9.7$ & 0.1 & $0.08 \pm 2.7$ & -3.5 & $17.977 \pm 2.5$ & 0.9555 \\
\hline
\end{tabular}

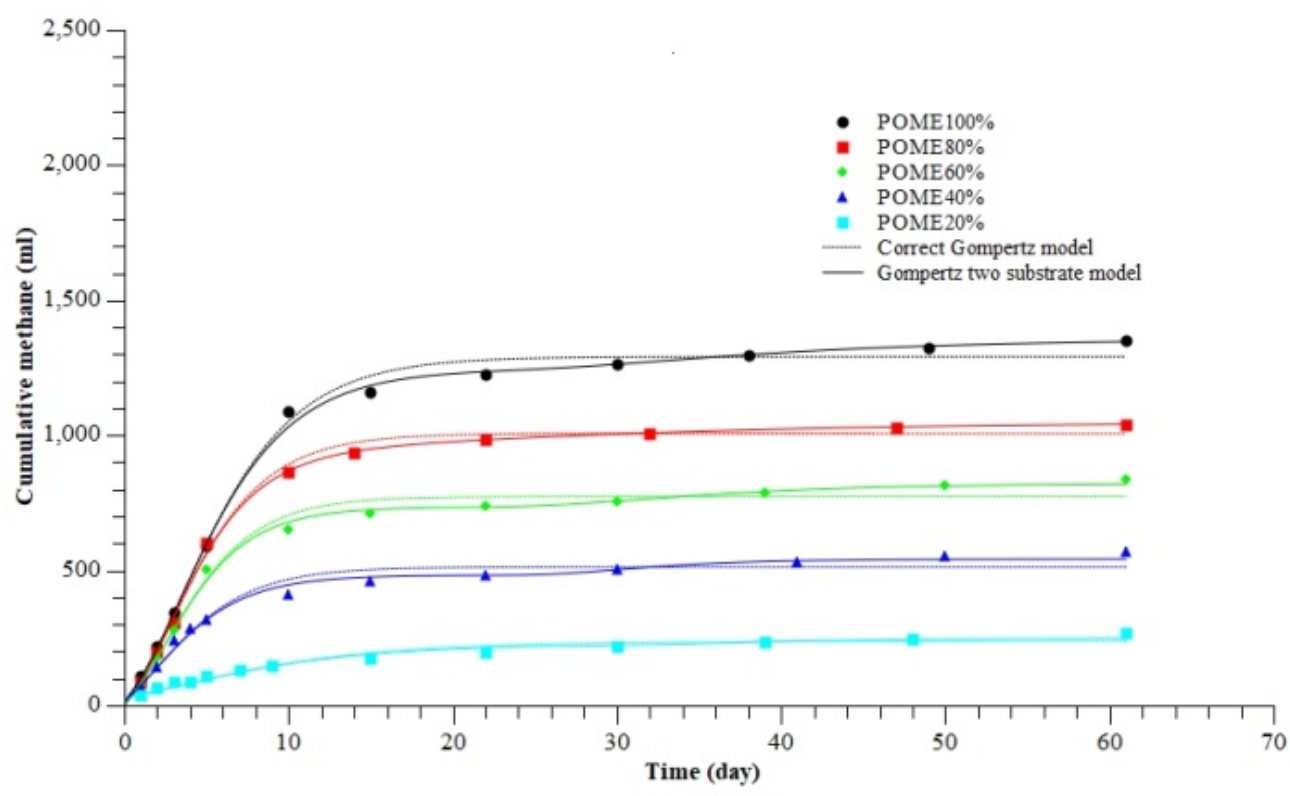

Figure 5 Comparison of experimental data and models from $\mathrm{S}_{1}$. 


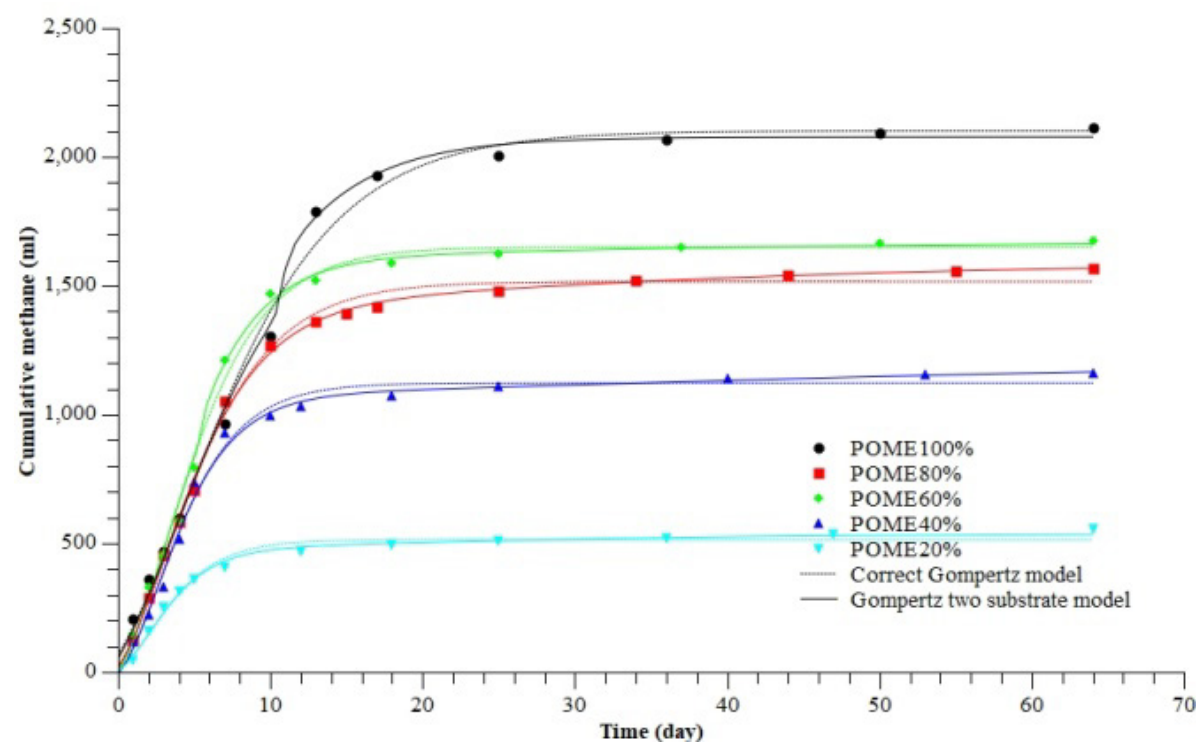

Figure 6 Comparison of experimental data and models from $\mathrm{S}_{2}$.

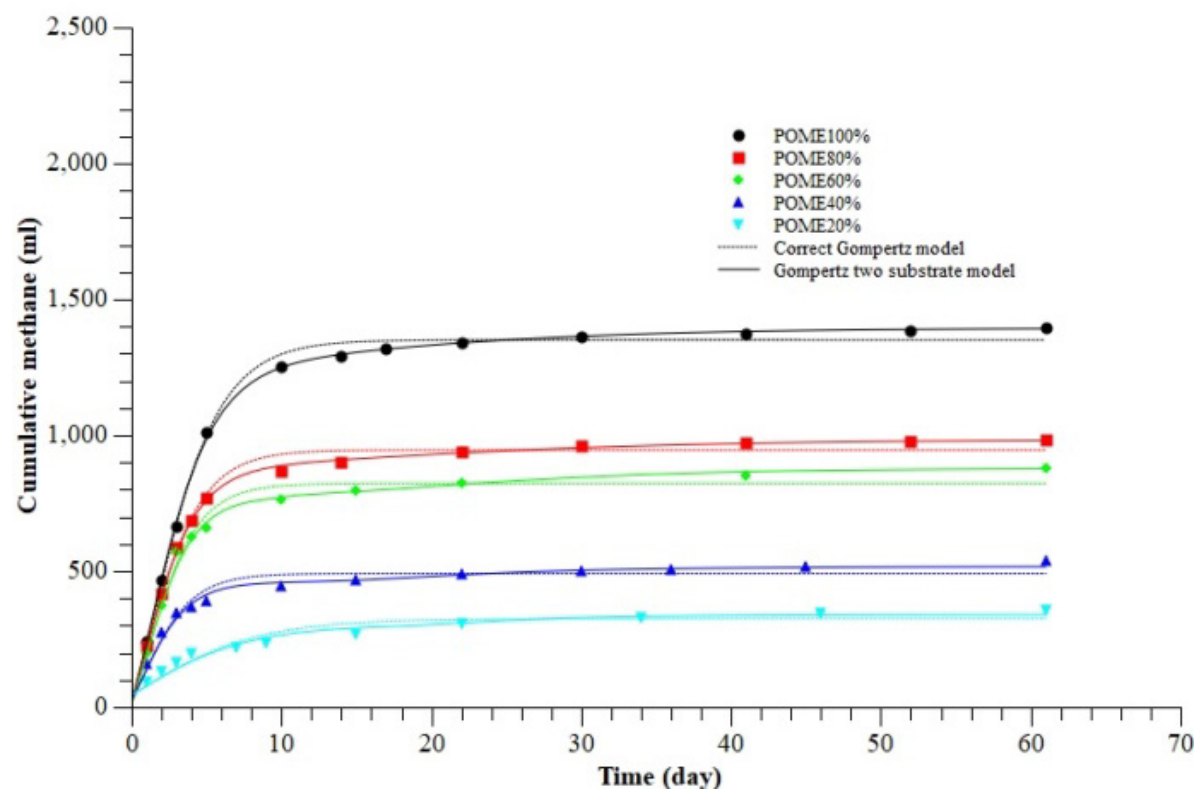

Figure 7 Comparison of experimental data and models from $\mathrm{S}_{3}$. 
http://wjst.wu.ac.th

\section{Conclusions}

Choosing inoculum or seed for the start-up of a new biogas plant or recovery from the previous system failure should be done carefully. BMP test provides a more direct way than that of the SMA test to evaluate how active was the potential inoculum. In the case of POME (as substrate), different dilutions should be explored to reduce the amount of inoculum to be transported from other sites, thus reducing the start-up cost. Although the BMP test is effective in predicting the performance of inoculum in general cases, more experiments should be conducted to find a suitable inoculum/POME ratio to mimic the startup process in practice where total cost and start-up time are the prime objectives. Therefore, this study concludes that Correct Gompertz and Gompertz two-substrate models were able to describe the experimental data very well. Furthermore, biomethane production rate can be obviously explained where a slightly better fit was observed with the Gompertz 2 substrate model. Gompertz 2 substrate model should be used to get insight and quantitative figures. If more insight is needed, more elaborated models like Monod 2 substrate model may be the better choice. However, for this research, Gompertz 2 substrate model was proven sufficient.

\section{Acknowledgements}

The authors would like to thank Walailak University Fund (06/60), Biomass and Oil-Palm excellence center Walailak University and the Ministry of Science and Technology of Thailand for the financial support. The authors would also like to express their gratitude to the coordinating center for Thai Government Science and Technology Scholarship Students (CSTS) National Science and Technology Development Agency (NSTDA).

\section{References}

[1] GD Najafpour, AAL Zinatizadeh, AR Mohamed, MH Isa and H Nasrollahzadeh. High-rate anaerobic digestion of palm oil mill effluent in an upflow anaerobic sludge-fixed film bioreactor. Process Biochem. 2006; 41, 370-9.

[2] KW Chou, I Norli and A Anees. Evaluation of the effect of temperature, $\mathrm{NaOH}$ concentration and time on solubilization of palm oil mill effluent (POME) using response surface methodology (RSM). Bioresource Tech. 2010; 101, 8616-22.

[3] PE Poh and MF Chong. Development of anaerobic digestion methods for palm oil mill effluent (POME) treatment. Bioresource Tech. 2009; 100, 1-9.

[4] J Ho and S Sung. Methanogenic activities in anaerobic membrane bioreactors (AnMBR) treating synthetic municipal wastewater. Bioresource Tech. 2010; 101, 2191-6.

[5] S Dechrugsa, D Kantachote and S Chaiprapat. Effects of inoculum to substrate ratio, substrate mix ratio and inoculum source on batch co-digestion of grass and pig manure. Bioresource Tech. 2013; 146, 101-8.

[6] MA Abdel-Hadi. A simple apparatus for biogas quality determination. Biol. Eng. 2008; 25, $1055-$ 66.

[7] WF Owen, DC Stuckey, JB Healy, LY Young and PL McCarty. Bioassay for monitoring biochemical methane potential and anaerobic toxicity. Water Res. 1979; 13, 485-92.

[8] JH Patil, A Raj, S Vinaykumar, H Manjunath, A Srinidhi. Biomethanation of water hyacinth, poultry litter, cow manure and primary sludge: A comparative analysis. Res. J. Chem. Sci. 2011; 1, 22-6.

[9] TH Ergüder, U Tezel, E Güven and GN Demirer. Anaerobic biotransformation and methane generation potential of cheese whey in batch and UASB reactors. Waste Manag. 2001; 21, 643-50.

[10] APHA, AWWA and WEF. Standard methods for the examination of water and wastewater. $19^{\text {th }} \mathrm{ed}$. American Public Health Association, Washington DC, 2005.

[11] C Siripatana, P Kongian, N Yingthavorn and N Rakmak. Mathematical modeling of existing two stage anaerobic digestion process for palm oil mill wastewater. Teknologi 2016; 78, 21-6. 
http://wjst.wu.ac.th

[12] L Noynoo, S Jijai, K Phayungphan, N Rakmak and C Siripatana. Gompertz-type two-substrate models for batch anaerobic co-digestion. Lecture Notes in Applied Mathematics and Applied Science in Engineering. Malaysia Technical Scientist Association, 2019, p. 21-30.

[13] DJ Batstone, J Keller, I Angelidaki, SV Kalyuzhnyi, SG Pavlostathis, A Rozzi, WTM Sanders, H Siegrist and VA Vavilin. The IWA Anaerobic Digestion Model No 1 (ADM1). Water Sci. Tech. 2002; 45, 65-73.

[14] W Choorit and P Wisarnwan. Effect of temperature on the anaerobic digestion of palm oil mill effluent. Electron. J. Biotechnol. 2007; 10, 376-85.

[15] S Jijai, S Muleng and C Siripatana. Effect of dilution and ash supplement on the bio-methane potential of palm oil mill effluent (POME). In: Proceedings of the $4^{\text {th }}$ International Conference on Research, Implementation, and Education of Mathematics and Science, AIP Publishing, 2017, 020013. 